\title{
Religion \& Suicide Acceptability: A Review \& Extension
}

\author{
By Steven Stack
}

\begin{abstract}
Religiosity has been a major, long standing construct in sociological analyses of suicide, but has received relatively less attention in other disciplines within Suicidology. Research on the four major explanations for a link between religiosity and suicide acceptability are reviewed: religious affiliation/integration, religious commitment, religious networks, and moral communities. Some special attention is directed to the proposition from religious commitment theory that religion offers a protection against hopelessness, a noted risk factor for suicide. A major limitation of existing work is that it remains disproportionately based on Western and more developed nations. This limitation is addressed through a new analysis of data from Wave $V$ of the World Values Surveys on 174,883 individuals nested in 80 nations including many Eastern and less developed countries. The results suggest something close to a sociological law: the greater the reported importance of religion, the lower the suicide acceptability. Future work is needed to ascertain to what extent the variability in the culture of religious hope contributes to this association.
\end{abstract}

Religiøsitet har lenge vært et viktig tema i sosiologiske analyser av selvmord, men har fått relativt liten oppmerksomhet innenfor andre retninger i suicidologien. I denne artikkelen redegjøres det for forskningen på de fire hovedforklaringene for sammenhengen mellom religiøsitet og i hvilke grad selvmord aksepteres som løsning: religiøs tilhørighet/integrasjon, religiøst engasjement, religiøse nettverk, og moralfelleskap. Et spesielt fokus rettes mot antakelsen fra teorien om religiøst engasjement at religion innebærer en beskyttelse mot håpløshet, en velkjent risikofaktor for selvmord. En betydelig begrensning i arbeidet som hittil er utført på dette feltet er at det er for sterkt basert på vestlige og mer utviklede land. Denne begrensningen forsøkes omgått gjennom en ny analyse av data fra World Values Surveys (Runde 5) der 174883 personer i 80 land deltok. Mange land i Øst og og mindre utviklede land deltok i denne undersøkelsen. Resultatene peker på noe i nærheten av en lovmessig sammenheng: Jo større betydning religionen oppleves å ha, i desto lavere grad aksepteres selvmord som løsning. Det er nødvendig å utføre videre forskning for å forstå i hvilken grad kulturelle variasjoner av religiøst håp bidrar til denne sammenhengen.

LEVERT: 02/12-12 REVIDERT: 19/03-13 AKSEPTERT: 03/04-13

\section{Introduction}

Religiosity tends to have a positive effect on a wide variety of measures of well being. These include (a) the risk of criminality, (b) the odds of substance abuse, hypertension, heart disease, stroke, disability, and enhances life expectancy. (c) generalized well being - happiness, life satisfaction, morale and positive affect, (d) social support (e) depression- although the findings of over 100 studies are mixed, the greater the religiosity level the lower the odds of depression and ( $\mathrm{f}$ ) stable, longer marriages (Baier \& Wright, 2001; Koenig, McCullough, \& Larson, 2001; Koenig, King \& Carson, 2012; MoreiraAlmedia, Neto, \&tKoenig, 2006; Schumaker, 1992). While much of this literature is based on American and Western samples, available research on other nations generally finds the same positive effect on well being measures. For example, religion was found to promote well being in a sample of 65 nations with varied socio-cultural frameworks (Elliott \& Haywood, 2009). In terms of suicide studies, although neglected in other subfields of suicidology, religion has served as one of the central constructs in the sociological work on suicidality (Colucci \&t Martin, 2008; Durkheim, 1897/1966; Stack, 1982, 2000b).

The present paper has several sections. First, it reviews the four principal theoretical perspectives on suicide and religion. Second, it reviews the empirical literature on religion's influence on one modality of suicidality: suicide acceptability (SA). The review section includes research that integrates all four perspectives (e.g., Stack Et Kposowa, 2011a). Third, given that the bulk of work on the subject is done on developed, Western nations, I extend the analysis to 80 nations including many Eastern countries. Finally the implications of the research to date for the four theories are discussed, and points of departure for future work are suggested.

This paper is focused on the link between religiosity indicators and one level of suicidality: suicide acceptability (SA). Studies that will be reviewed need to report at least one empirical finding between a measure of religiosity and a measure of SA.

\section{Significance of Suicide Acceptability}

The significance of suicide acceptability is evidenced by its association with a variety of well-studied constructs in suicide studies. SA is often predictive of suicide thoughts or ideation (e.g., Dervic, Gruebaum, et al., 2006), attempted suicide (e.g., Joe, Romer \&t Jamieson, 2007), and suicide completions at the aggregate level (e.g., Cutright \& Fernquist, 2008; Stack Et Kposowa, 2008). Joe, Romer, \&t Jamieson (2007) determined, for example, in a study based on a national representative sample of 3,301 youth, that those who believe that suicide is acceptable are 12.7 times more apt to make a plan to kill themselves than their counterparts. A multidimensional index of suicide acceptability was related to suicide ideation among both American and Ghanaian college students (Eshun, 2003). In an analysis of suicide rates in the 50 American states, Cutright \&t Fernquist (2004) showed that the higher the mean level of suicide acceptability the higher the state's suicide rate. Neeleman, Halpern, Leon, \&t Lewis (1997), in an analysis of 19 Western nations, showed that the greater the level of suicide acceptability, the higher the suicide rate. For an exception to this pattern see Lester (1988).

\section{Four sociological theories of religiosity \& suicide}

The link between religiosity and suicide acceptability has been made through four interpretative frameworks: religious integration, religious commitment, religious networks, and moral communities. These approaches are not mutually exclusive.

They are seen as complimentary. However, most of the research on the subject tends to adopt one or two of these approaches.

\section{Religious Integration}

According to religious integration theory (Durkheim, 1897/ 1966), an individual is integrated into religious life to the extent that $s /$ he adheres to shared religious beliefs and practices. 


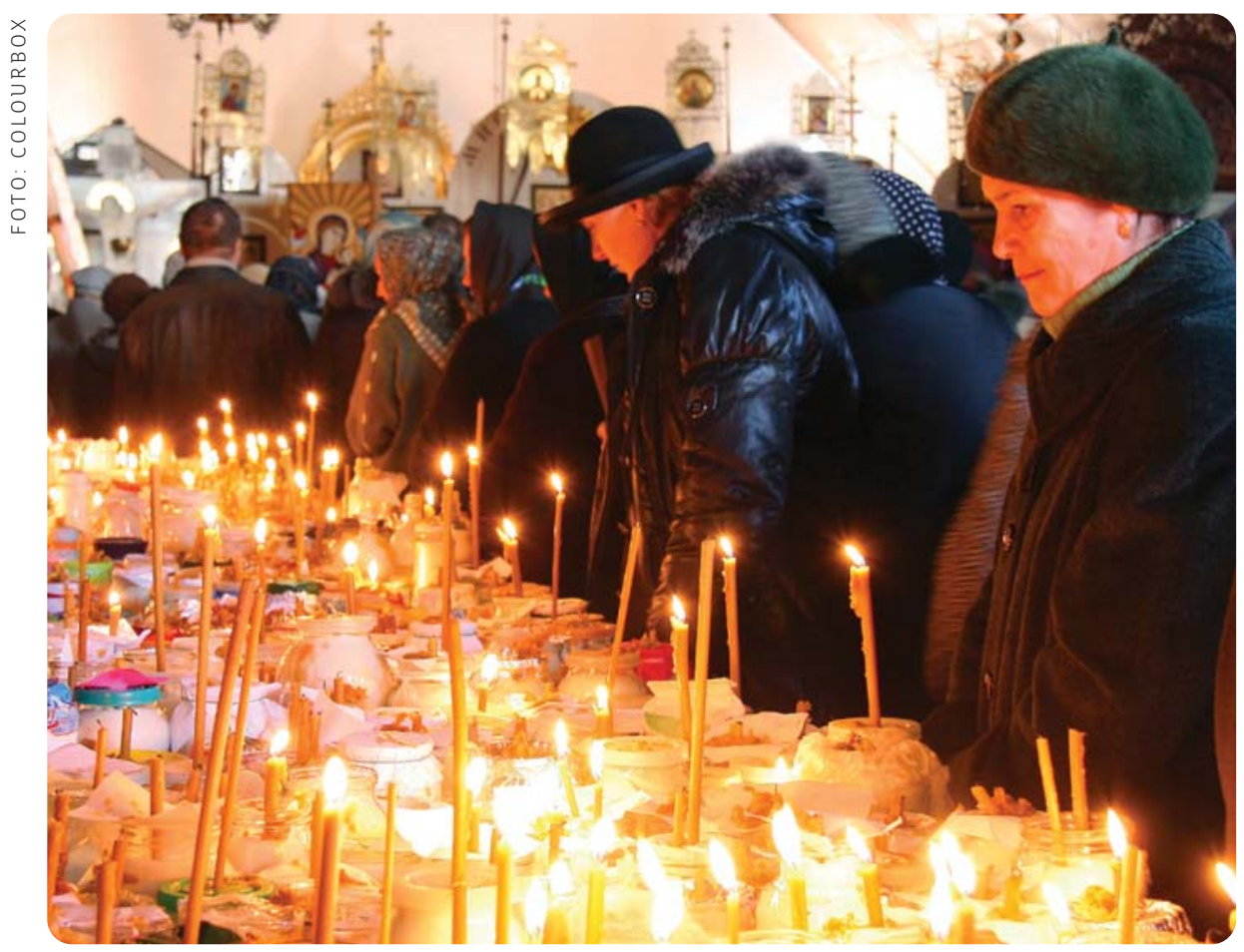

The greater the number of such beliefs and practices the higher the integration and, the lower the risk of suicide (Durk heim, 1897/1966). The content of such beliefs is not as important as the sheer number. Durkheim (incorrectly by today's standards) argued that religions prohibit suicide with roughly the same intensity, so the real issue is the number of beliefs. As a consequence, if one religion has higher integration than another, the former should have a lower suicide rate. In Durkheim's day, since Catholics had more shared religious beliefs and practices than Protestants (e.g., meatless Fridays, no divorce, the institution of confession), Durkheim attributed the often higher suicide rate of Protestants (in most cases they were $50 \%$ or more higher than those of Catholics) to their lower level of integration. Given fewer rules and shared practices, Protestants did not have to subordinate themselves as much as Catholics to collective life. Such subordination gives life meaning and detracts the individual from dwelling on their own problems.

However, since Durkheim's day, there has been a trend towards convergence between Catholics and Protestant orthodoxy and the frequency of religious practice, including a key behavior: church attendance (Stack, 1983; 2000b). This convergence has been associated with the reporting of more insignificant findings between religious affiliation and suicidality, based on the Catholic vs. Protestant measure of religion.

\section{Religious Commitment}

In contrast to Durkheim's emphasis on the number of shared beliefs, Stack (1983) contended that adherence to a few lifesaving beliefs might be enough to save lives from suicide. A belief in the notion that Jesus walked on water or fed thousands with a few baskets of food, may not carry the same protective impact as a belief in a blissful afterlife as a reward for good behavior. A belief in an afterlife, in particular, can provide hope for the many who suffer through trauma, turmoil, divorce, impoverishment, extreme loneliness, repeated betrayals, physical handicaps, and other burdens of living. Religion can protect against suicide by promoting hopefulness, hopefulness of a blissful afterlife (Koenig, McCullough, \& Larson, 2001).
Religious Commitment \& Protection Against Hopelessness

Numerous studies have demonstrated a link between religiousness and hope/optimism (see review in Koenig, McCullough \& Larson, 2001). Hopelessness is considered a major risk factor for suicide (Beck Steer, et al., 1985; Beck, Brown, et al., 1990; McMillan, Gil-body, et al., 2007). Hopelessness promotes the odds of suicide by its negative view of outcomes for the future. For example, Beck et al. (1990) reported that people scoring above a standard cutoff ( 9 or higher on the 20 point hopelessness scale), were fully 11 times more likely to die by suicide $(17 / 1,161$ patients) than their counterparts with low scores (1/797 patients). Beck et al (1990) do note the large number of false positives. There is no systematic discussion of religiosity in the classic works on hopelessness and suicide (e.g., Beck et al, 1985; Beck et al., 1990). A meta analysis of psychiatric work on the subject also fails to discuss religiosity's role as reducing hopelessness for some persons at risk (McMillan, et al., 2007). The extent to which persons who suicide due to hopelessness are also low in religiosity, is generally not explored.

In contrast to psychiatric writing on hopelessness, which tends to ignore religion, sociological work on religious commitment theory sees religion as providing a set of cognitive coping mechanisms for hopelessness. The belief in a blissful afterlife can help persons endure earthly sufferings such as divorce, unemployment, dysfunctional families, serious illnesses, physical disabilities and so on. Suffering is also defined as temporary. In Christian religious belief systems, our lives are but a moment in time compared to eternity in the here-after (Stack 1983; 1992).

A belief in a last judgment day can also assuage worldly suffering (e.g., Stack, 1983; 1992). Victims of perceived injustice can derive some satisfaction and help from a belief that their tormentors will be punished in the hereafter, with the worst wrong doers being damned on the day of judgment. 
In Christian teaching there is the doctrine that "Vengeance is mine, says the Lord", referring to harsh judgments on perceived evil doers in the afterlife. Without such a belief in justice in the hereafter, suffering at the hands of perceived evil doers can be more difficult to bear, especially if avenues towards justice in the here and now are perceived as being blocked.

Other Christian beliefs, which are thought to assuage suffering, and reduce depression, are viewed as protection against suicide (Stack 1983; 1992). A belief in a responsive God, one who is aware of your sufferings and answers prayers can protect against loneliness. For the poor, the belief that it is easier for a camel to go through the eye of a needle than for a rich man to enter the Kingdom of heaven, can contribute to the endurance of economic strain. More generally, religion offers an alternative stratification or ranking system based on morality not money and possessions. Losers in the societal rat race for success can turn to this alternative stratification system to build self esteem. Finally religions often offer important role models for enduring adversity. These include, Job in the Christian Bible, who endures all manner of worldly suffering including disease, death of loved ones and impoverishment but does not resort to suicidality. Martyrs can also function as role models for the endurance of suffering.

It should be noted that church attendance, a key measure of shared religious practices in religious integration theory, can also reinforce adherence to a few religious beliefs marking religious commitment theory. It has been used as a measure of both theories.

\section{Religious Networks Theory}

A third perspective argues that it is not so much religious beliefs that protect religious individuals from suicidal behavior, but the social support that can be derived from membership in religious groups. Using aggregated data on suicide rates in American counties, Pescosolido \& Georgiana (1989) determined that countries with high proportions of religious denominations that provide the greatest opportunities for social networks, were the ones with relatively low suicide rates.

\section{Moral Communities}

The essence of the moral communities thesis is that individual level religiosity will be maximized to the extent that the individual is nested into a community of like-minded individuals (Stack \& Kposowa, 2011a). For example, in the context of a state religion, present in some Muslim nations today, everyone has the same religion. In that context, the beliefs and practices of all individuals are automatically reinforced by everyone around him/her. In contrast, a Muslim living in a small town in an overwhelming Christian nation may have no one to reinforce his/her beliefs. The protective effect of religious systems is proportional to the size of the same religious group surrounding the individual. However, religious systems may actually reach out and protect non religious individuals, especially where non religious individuals are a small minority of the population.

\section{Empirical work on religion and suicide acceptability}

Due to space limitations, the review is selective and gives priority to investigations based on large, representative samples of the population. These should provide more generalizable findings than research based on small non representative samples. In general, most of the studies, and findings contained within the relevant studies, bear mixed support. However, the bulk of the work generally finds the greater the religiosity, the lower the level of suicide acceptability. We make a distinction between research based on U.S. samples and research based on samples from other nations.

\section{American Based Research}

Much of the relevant research on suicide acceptability and religion is based on the General Social Surveys (GSS), a biannual survey funded by the National Science
Foundation of a national representative sample of non institutionalized adults. The available measures of SA are four questions regarding the acceptability of suicide in four contexts: terminal illness, bankruptcy, dishonoring one's family, and tired of living. Early work on 1,380 respondents in the 1982 GSS determined that, controlling for several socio-demographic variables, weekly church attendance and the strength of religious preferences (from not strong through strong) lowered SA (Sawyer, \&t Sobal, 1987). Analyses of the four SA items taken separately yielded mixed results but the authors concluded that low religiosity tends to enhance SA (Singh, Williams, \&t Ryther, 1986).

The most systematic analysis of the topic was reported by Agnew (1998) and was based on the 1990-1991 GSS. At the bivariate level the following measures of religion lowered SA: belief in an afterlife, literal interpretation of the bible, fundamentalism, and church membership. These associations held up under controls for a variety of 21 socio-economic variables. Most other investigations based on the GSS explored fewer dimensions of religiosity. Stack (1998b) added an analysis of race specific data of the pooled 19741994 GSS. Church attendance and fundamentalism lowered suicide acceptability for both blacks and whites. Stack \& Wasserman (1995) found evidence that while religion was associated with low levels of SA for both whites and blacks, religiosity had a stronger effect for whites than blacks. Another race specific analysis by Neeleman, Wessley, \& Lewis (1998) also found a lower level of SA among blacks as compared to whites. The authors attributed this particular difference to the relatively high level of religious orthodoxy among blacks.

Stack \& Wasserman (1992) analyzed the GSS years 1977-1990 to test aspects of Pescosolido and Georgiana's (1989) religious network theory of suicide. Members of churches thought to promote social network involvement (e.g., those with conservative theologies or nonecumenical relations) were lower in SA than their counterparts. 
Additional papers on SA reported a link between low church attendance (a measure of exposure to religious beliefs and social networks) and high SA (Stack, 1996a; 1996b; 2000c; 2002; Stack, Wasserman, \& Kposowa, 1994). A paper by Stack \&t Lester (1991) also linked low SA and high church attendance, and also included Catholicism, which did not predict SA. Generally, all analyses using the GSS report at least some support, and usually strong support, for a link between measures of religion and suicide acceptability.

Joe et al., (2007) analyzed data on 3,301 youths ages 14-22 from a representative sample in the National Annenberg Risk Survey of Youth. Controlling for sociodemographic factors, a one unit change in the index of religiosity lowered the chances of the approval of suicide by $37 \%$.

\section{Cross-National, Single Nation Studies}

In a multivariate analysis of data from the 2004 Moscow Health Survey, Jukkala \& Makinen (2011) determined that non religious persons were more accepting of suicide than religious persons. The impact of religion was independent of eight socio-economic and cultural variables. An analysis of the Dutch Family Survey found that an index of core Christian religious beliefs (e.g., afterlife, God, Hell) predicted lower suicide acceptability and lower acceptability of euthanasia (Scheepers, \&t van der Slik, 1998).

\section{Cross National, Multiple Nation Studies}

Much of the work on SA at the comparative level has been based on the five waves of the World Values Surveys (WVS) ranging from 1981 through 2005 (e.g., Stack, 1998a; Stack \&t Kposowa, 2008; 2011a;2011b). The number of nations included has increased from a few dozen to over 100, and now includes a majority of the world's population. The main measure of SA is a single item: "Is suicide always wrong, always right, or somewhere in between?", with responses ranging from 1 through 10.

The first work tested Stack's (1983) notion of religious commitment to a set of 22 religious beliefs, combined with items on the importance of religion, on SA among 28,085 subjects in Wave II of the WVS in 19 Western nations (Neeleman, Halpern, et al., 1997). The index of religious beliefs/importance predicted the level of respondent SA even after controlling for religious attendance and other socio-demographics. Subsequent work on 13,337 persons nested in 15 nations in Wave I of the WVS showed that the frequency of church attendance was associated with low levels of SA. The association was independent of controls for 8 socio-demographic risk factors and national character (Stack, 1998a).

However, such a finding is difficult to interpret with a specific theory. As noted earlier, church attendance can act simultaneously as a measure of integration in terms of exposure to religious beliefs and practices, as well as a measure of religious commitment in terms of exposure to the central life saving beliefs of religion. In addition, church attendance can lead to social network formation with co-religionists. These can foster psychological gains and social support described in religious networks theory.

A subsequent paper included church attendance and a measure of self defined religiousness, meaning religious, non religious or atheist. In an analysis of wave II of the WVS, involving 40,873 persons in 31 nations, Stack \& Kposowa (2008) determined that the greater the church attendance, the lower the SA. Also, religious persons were less approving than non religious persons, while atheists were the most approving of all. Still, no measures were included for specific beliefs from religious commitment theory and no measure of the strength of networks with coreligionists. Another paper focused on predicting the level of SA among 3,580 black males residing in ten mostly less developed nations. Stack \& Kposowa (2011b) again reported that the higher the church attendance, the lower the SA for this particular group.

Given the ambiguity of exactly which theory of religion is best supported by these early findings, subsequent work was able

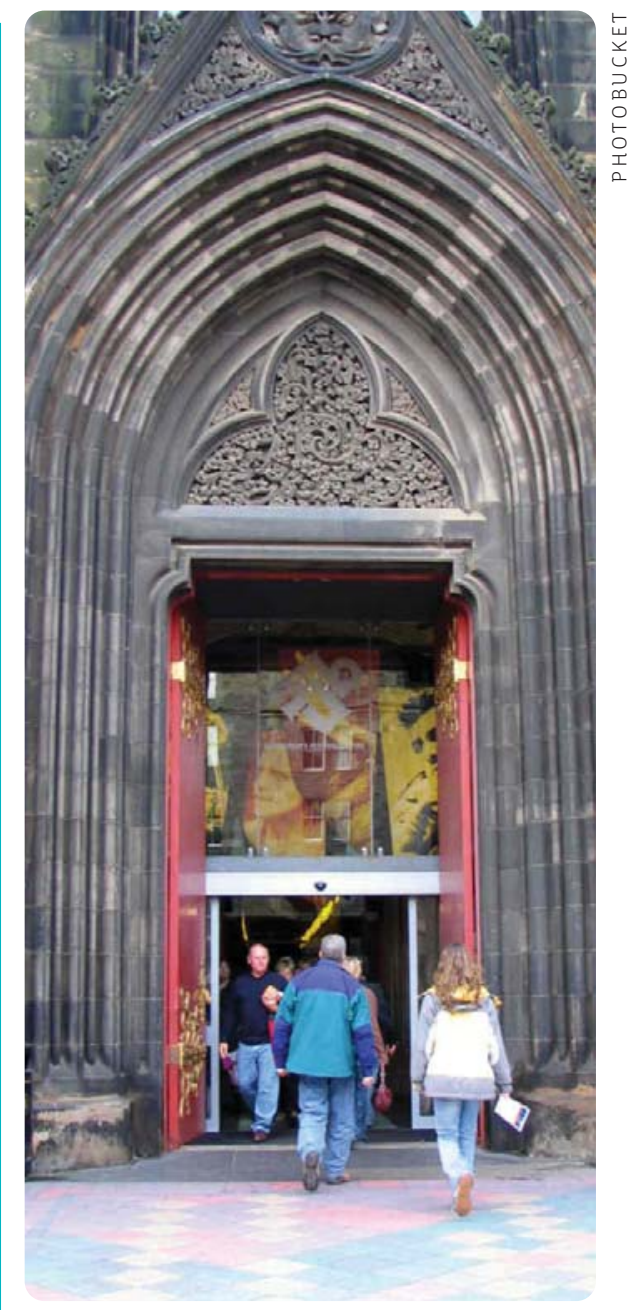

to incorporate separate measures for each of the four major sociological theories of religion and suicide. Stack \& Kposowa (2011a) employed data from wave IV of the WVS on 50,547 persons residing in 56 countries. Durkheim's emphasis on religious affiliation was reformulated to compare persons affiliated with each of seven major religious groups (e.g., Buddhist, Catholic, Hindu, Islam, Orthodox, Protestant, Other), to persons with no affiliation. Data on the incidence of suicidality for Eastern religions (which often are higher in integration, including Islam) were unavailable in Durkheim's day. Religious commitment theory was measured in relation to core religious beliefs thought to assuage suffering including belief in an afterlife. Religious network theory was captured by a question on how much time the subject spent with coreligionists. 
Table 1. The effect of the importance of religion on suicide acceptability: Standardized regression coefficient for religious $i$ mportance from regression analyses for each of 80 nations, World Values Surveys, Wave V, 2005.

\begin{tabular}{|c|c|c|c|c|c|}
\hline - Albania & $.066^{*}$ & - Georgia & $-.113^{*}$ & - Puerto Rico & $-.156^{*} \#$ \\
\hline - Algeria & $-.084^{*}$ & - Germany & $-.123^{*}$ & - Romania & $-.104^{*}$ \\
\hline - Andorra & $-.202^{*} \#$ & - Ghana & $-.070^{*}$ & - Russian Federation & $-.094^{*}$ \\
\hline - Argentina & $-.183^{*} \#$ & - Great Britain & $-.162^{*}$ & - Rwanda & -.020 \\
\hline - Armenia & $-.066^{*}$ & - Guatemala & $.056 \mathrm{~ns}$ & - Serbia & -.058 \\
\hline - Australia & $-.216^{*} \#$ & - Hungary & $-.169^{*} \#$ & - Serbia \& Montenegro & $-.087^{*}$ \\
\hline - Azerbaijan & $.096^{*}$ & - India & $-.036^{*}$ & - Slovakia & $-.283^{*} \#$ \\
\hline - Bangladesh & -.004 ns & - Indonesia & $-.074^{*}$ & - Slovenia & $-.145^{*}$ \\
\hline - Belarus & $-.115^{*} \#$ & - Italy & $-.248^{*} \#$ & - South Africa & $-.134^{*}$ \\
\hline - Bosnia \& Herzegovina & $-.108^{*}$ & - Japan & $-.151^{*}$ & - South Korea & $-.194^{*}$ \\
\hline - Brazil & $-.078^{*}$ & - Jordon & $-.076^{*}$ & - Spain & $-.160^{*}$ \\
\hline - Bulgaria & $-.102^{*}$ & - Krygyzstan & $-.135^{*}$ & - Sweden & -.059 \\
\hline - Burkina Faso & -.043 & - Latvia & $-.284^{*} \#$ & - Switzerland & $-.201^{*}$ \\
\hline - Canada & $-.233^{*} \#$ & - Lithuania & $-.258^{*}$ & - Taiwan & $-.104^{*}$ \\
\hline - Chile & $-.138 * \#$ & - Macedonia & $-.067^{*}$ & - Tanzania & -.046 \\
\hline - China & -.050 ns & - Malaysia & -.043 & - Thailand & $-.159^{*} \#$ \\
\hline - Columbia & $-.067^{*}$ & - Mali & -.009 & - Trinidad \& Tobago & -.037 \\
\hline - Croatia & $-.246^{*} \#$ & - Mexico & $-.107^{*}$ & - Turkey & $-.149^{*}$ \\
\hline - Cyprus & $-.238^{*} \#$ & - Moldova & $-.108^{*}$ & - Uganda & $-.118^{*} \#$ \\
\hline - Czech Republic & $-.096^{*}$ & - Netherlands & $-.233^{*}$ & - Ukraine & $-.104^{*}$ \\
\hline - Dominican Republic & $-.197^{*} \#$ & - New Zealand & $-.199^{*} \#$ & - Uruguay & $-.081^{*}$ \\
\hline - Egypt & -.023 & - Nigeria & $-.031^{*}$ & - USA & $-.276^{*} \#$ \\
\hline - El Salvador & $-.081^{*}$ & - Norway & $-.059^{*}$ & - Venezuela & -.003 \\
\hline - Ethiopia & $-.277^{*} \#$ & - Pakistan & $-.060^{*}$ & - Vietnam & .001 \\
\hline - Estonia & $-.127^{*}$ & - Peru & $-.038^{*}$ & - Zambia & -.003 \\
\hline - Finland & $-.187^{*}$ & - The Philippines & -.033 & - Zimbabwe & $-.057^{*}$ \\
\hline - France & $-.157^{*}$ & - Poland & $-.142^{*}$ & & 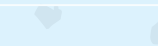 \\
\hline
\end{tabular}

*p $<.05$, for corresponding t-statistic, one tailed test

\# = Religious importance is the most important predictor of suicide acceptability in nation.

Note: Controls variables (not shown) include: Gender, age, financial satisfaction, marital status, self reported satisfaction with health, \&t Self Expressionist Cultural Values.

Finally, the level of religiosity of the nation where the respondent resided was measured (as the mean level of church attendance in a nation) to assess the moral communities perspective. Controls were incorporated for a variety of socio-demographic variables including the level of economic development of the nation of residence, and the gender, age, marital status, political liberalism, life satisfaction, and social class status of the respondent. Controlling for the socio-demographic variables, all measures of religion and religiosity were associated with lower levels of SA. That is, there was a correspondence between high levels of religiosity on all the different measures of religiosity and low SA. In addition, church attendance lowered suicide acceptability as expected from previous work. Finally, a new item "religion gives me strength and comfort" also lowered suicide acceptability. This new item can be taken as a measure of religious commitment theory or possibly religious integration. This paper stands as the most systematic test of the impact of religion on suicide acceptability given that it tests all four sociological theories of religion and suicide and includes a variety of nations at different levels of development, different religious traditions, and, in general, different socio-cultural structures. The results suggest that the four theories are complimentary to one another, all contribute to the variance in suicide acceptability explained by religion.

\section{Analysis: extension to 80 nations}

The present analysis further extends the work of Stack \& Kposowa (2011a) to include 80 nations. In addition, it explores within nation variation in the effect of religion on suicide, something not done in the previous paper. Deviant cases are best found by exploring each nation one at a time. Otherwise deviant cases may remain hidden when nations are lumped together in a single analysis. Any exceptions to a general rule may help to explain further variability in the link between religion and suicide by locating contexts where the link does not exist. The extension is based on the largest data set on religion and suicide acceptability, Wave $\mathrm{V}$ of the World Values Surveys.
Of the several measures of religion available, the present analysis chose the item on the importance of religion to the subject. This item is available for the greatest number of nations and is correlated with other dimensions of religiosity.

As in the past work, controls were introduced for gender, age, financial satisfaction, marital status, satisfaction with overall health, and a cultural axis of nations self expressionism (for details on the measure-ment and meaning of these constructs see Stack \&t Kposowa, 2011a; 2011b). Complete data were available for 174,883 persons nested in 80 nations.

A multiple regression analysis was run for each of the 80 nations taken separately. The results of the 80 multiple regressions are presented in Table 1. For purposes of brevity and clarity, only the beta coefficient for religiosity is shown. In 64 of the 80 nations religiosity served as a protective factor against suicide acceptability. Controlling for the other six variables, the greater the reported religiosity, the lower the acceptability of suicide. Further, from rank ordering the relative sizes of the 7 predictor variables, religiosity was 
the most important predictor of low levels of suicide acceptability in 19 nations.

The importance of religiosity in predicting SA was found in the various "culture zones" of the world. Culture zones generally refer to groups of nations with a common religious heritage.

There are approximately a dozen, but the exact number, and the number of nations in each zone, varies according to the defini-tions in force (e.g., Huntington 1993; 1996; Inglehart \&t Baker, 2000). According to Inglehart \& Baker (2000) these zones include the Buddhist zone (e.g., Japan, Thailand), the former communist zone (e.g., Estonia, Hungary, Latvia, Russian Federation), the Orthodox zone which overlaps somewhat with the former communist zone (e.g., Armenia, Bulgaria, Romania, Russian Federation),Confucian zone (South Korea, but not China). Islamic zone (e.g., Algeria, Bangladesh, Jordon, Pakistan, Turkey), Protestant Europe (e.g., Norway, Sweden), Catholic Europe (e.g., France, Spain), Africa (Nigeria, Rwanda), Latin America (e.g., Argentina, Peru), and English speaking zones (e.g., Australia, New Zealand, US). The link between religiosity and SA is apparently found in at least some nations in all culture zones. It is not being dependent on, for example, a particular religious tradition.

There were 16 deviant cases where religiosity was not related to SA independent of controls. With the exception of Sweden, these are less developed nations and include Bangladesh, Mali, Rwanda, Tanzania, Vietnam, and Zambia. The rather low level of religiosity in Sweden may account for its departure from the norm.

However, in some of these nations religion was a protective factor before 6 control variables were entered into the analysis. In others the degree of SA was so low (e.g., $99 \%$ of the population reported suicide was always wrong in some Islamic nations) it was difficult for any variable to predict SA since the latter was essentially a constant. Further work is needed to fully explain the sources of these deviant cases.

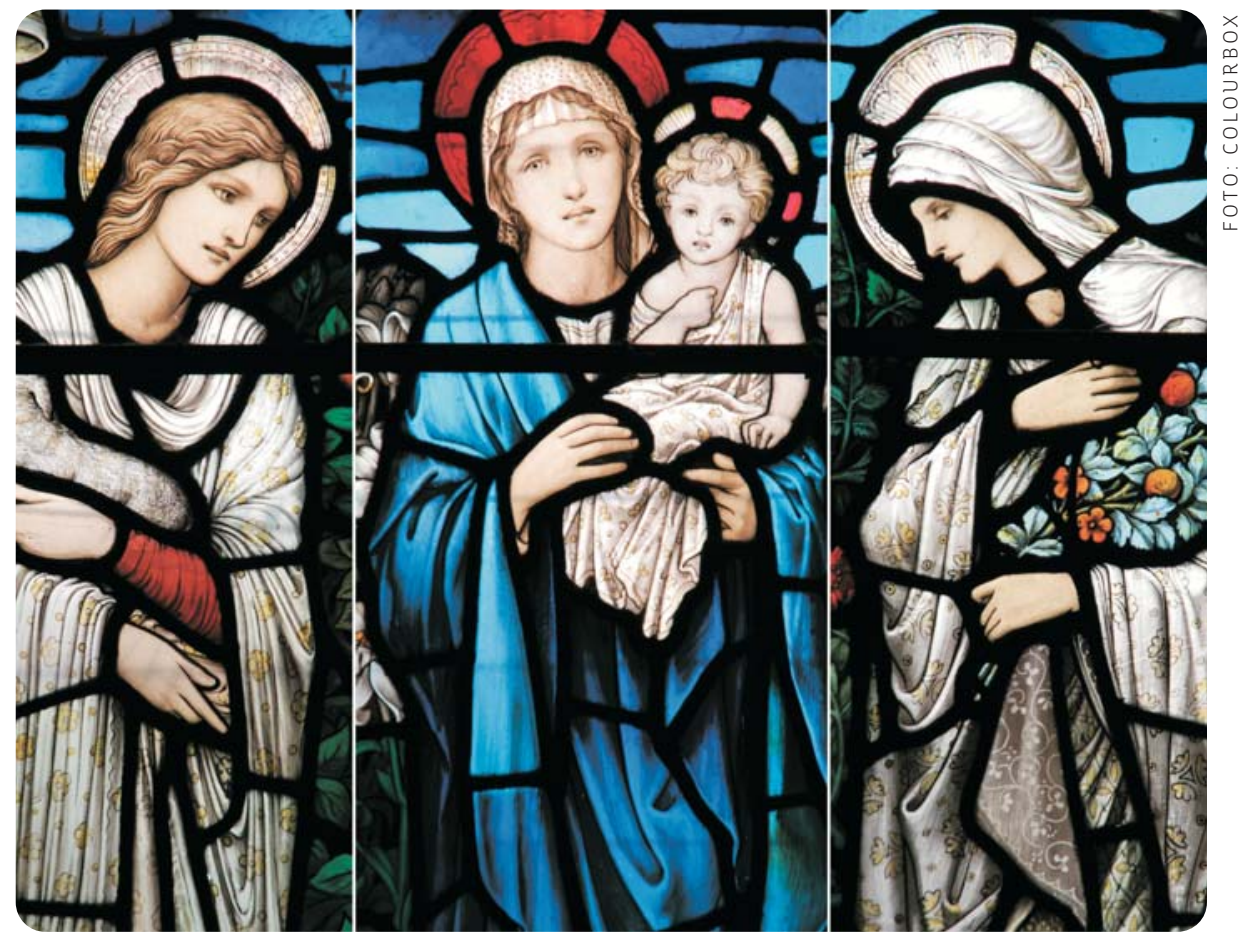

\section{Conclusions}

Suicide acceptability is a relatively neglected modality of suicide. Compared to the voluminous literature on predicting suicide ideation, attempts, and completions, there is little on suicide acceptability. Nevertheless, SA predicts other modalities of suicidality.

Religiosity is among the best predictors of suicide acceptability. Most of the research on religion and SA has been done on Western nations. However, recent work, including the present analysis of 80 nations from all major culture zones in the world, finds that religiosity is associated with a lower level of SA in many Eastern as well as Western nations.

Future work is needed to understand the variation in the strength of the association between religiosity and suicide acceptability. The relative sizes of the significant negative Beta coefficients in Table 1 range in size from -.031 in Nigeria to a high of -.284 in Latvia. Possible contributors to this variation in the association might include religious tradition, frequency of attendance at religious services where religious belief systems are reinforced and protective social networks are formed, the relative sizes of moral communities which can reinforce norms against suicide for believers and non believers alike, and the relative strength of other supportive institutions such as the family that protect against suicide (Stack, 2000a; 2000b). For example, a strong family system combined with a strong religious system may deter suicide more than a strong religious system not backed up by a strong family system.

In particular, there was considerable support for the religious commitment theory. Many investigations found linkages between key religious beliefs (e.g., belief in an afterlife), often a reward for enduring suffering. While a promise of a blissful afterlife can certainly promote a sense of hopefulness, this connection has been neglected in the suicide and hopelessness literature (e.g., Beck et al, 1985; Beck et al., 1990; see review in McMillan, et al., 2007). Future work on hopelessness and SA could be strengthened by including an index religiosity. The inclusion of religiosity may reduce the large number of false positives already noted in such work (McMillan, et al., 2007). 
Many of the propositions from the four theories have not been systematically tested. For example, future work is needed on many of the specific beliefs thought to save lives from suicide in religious commitment theory. Items on beliefs such as the last judgment day, belief in a responsive God who hears prayers, a belief that suffering has a supernatural purpose being part of God's will to teach us the value of perseverance, are in need of study.

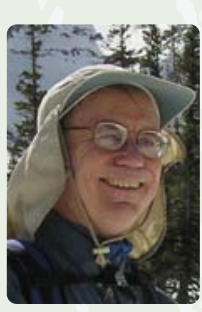

Dr. Steven Stack is a Professor at Wayne State University with appointments in the departments of psychiatry and criminology. He has published 294 articles, chapters, and two books mostly on the social risk and protective factors for suicide. These have recived over 3,600 citations in Social Sciences Citations Index. His recent book (with Barbara Bowman) is the first to analyze the portrayals of suicide in film: Suicide Movies: Social Patterns, 19002009. Boston: Hogrefe, 2011

\section{References}

Agnew, R. (1998). The approval of suicide: A social psychological model. Suicide \&t Life Threatening Behavior,28, 205-225.

Baier, C. \& Wright, B.R.E. (2001). If you love me keep my commandments: A Meta analysis of the effect of religion on crime. Journal of Research on Crime \& Delinquency, 38, 3-21.

Beck. A.T., Steer, R.A., Kovacs, M., et al., (1985). Hopelessness and eventual suicide: a ten year prospective study of patients hospitalized with suicide ideation. American Journal of Psychiatry, $142,559-563$.

Beck. A.T., Brown, G., Berchick, R. J., Stewart, B.L., \&t Steer, R.A. (1990). Relationship between hopelessness and ultimate suicide: A replication with psychiatric outpatients. American Journal of Psychiatry, 147, 190-195.

Colucci, E., \&t Martin, G. (2008). Religion \&t spirituality along the suicidal path. Suicide \& Life Threatening Behavior, 38, 229-244.

Cutright, P. \&t Fernquist, R. M. (2004). The culture of suicide through societal integration and regulation: 1996-1998 gender specific suicide rates in the 50 states. Archives of Suicide Research, 8, 271-285.

Cutright, P., \&t Fernquist, R.M. (2008). Three explanations of marital status differences in suicide rates: social integration, marital status integration and the culture of suicide. Omega, 56, 175-190.
Dervic, K., Grunebaum, M.F., Burke, A.K., Mann, J.J., Oquendo, M. (2006). Protective factors against suicidal behavior in depressed adults reporting childhood abuse. The Journal of Nervous \& Mental Disease, 194, 971-974.

Durkheim, E. (1897/1966). Suicide. New York: Free Press.

Elliott, M. \& Haywood, R.D. (2009). Religion and life satisfaction worldwide. Sociology of Religion, 70, 285-310.

Eshun, S. (2003). Socio-cultural determinants of suicide ideation: A comparison between American and Ghanaian college samples. Suicide \& Life Threatening Behavior, 33, 165-171.

Huntington, S.P. (1993). The clash of civilizations. Foreign Affairs, 72, 22-49.

Huntington, S.P. (1996). The Clash of Civilizations \& $t$ the remaking of the World Order. New York: Simon \& Schuster.

Inglehart, R. \& Baker, W.E. (2000). Modernization, cultural change, and the persistence of traditiona values. American Sociological Review, 65, 19-51.

Joe, S., Romer, D.D., \&t Jamieson, P.E. (2007). Suicide acceptability is related to suicide planning in U.S. adolescents and young adults. Suicide \&t Life Threatening Behavior, 37, 165-178.

Jukkala, T. \& Makinen, I.H. (2011). Acceptance of suicide in Moscow. Social Psychiatry \& Psychiatric Epidemiology, 46, 753-765.

Koenig, H. G., McCullough, M.E., \&t Larson, D. B. (2001) Handbook of Religion \& Health. New York: Oxford University Press. New York: Oxford University Press. Koenig, H.G., King, D. \& Carson, V.B. (2012). Handbook of Religion and Health. New York: Oxford University Press.

Lester, D. (1988). Societal approval of suicide. Psycho-logical Reports, 62, 958.

McMillan, D.M., Gilbody, S., Bersford, E., \&t Neilly, L. (2007). Can we predict suicide and non fatal self harm with the Beck hopelessness scale? A Meta analysis. Psychological Medicine, 37, 769-778.

Moreira-Almeida, A., Neto, F.L., \&t Koenig, H. (2006). Religiousness \&t mental health: A review. Rev Bras Psiquiatr., 28, 242-250.

Neeleman, J., Halpern, D, Leon, D, \&t Lewis, G. (1997). Tolerance of suicide, religion, and suicide rates: An ecological and individual study in 19 Western countries. Psychological Medicine, 27, 1165-1171.

Neeleman, J., Wessley, S., \&t Lewis, G. (1998). Suicide acceptability in African - and white Americans: The role of religion. The Journal of Nervous and Mental Disease, 186, 12-16.

Pescosolido, B., \&t Georgiana, S. (1989). Durkheim, suicide \& religion: Toward a network theory of suicide. American Sociological Review, 54, 33-48.

Sawyer, D., \&t Sobal, J. (1987). Public attitudes toward suicide: demographic \& ideological correlates. Public Opinion Quarterly, 51, 92-101.

Scheepers, P., \&t van der Slik, F. (1998). Religion and attitudes on moral issues: Effects of individual, spouse and parental characteristics. Journal for the Scientific Study of Religion, 37, 678-691.
Schumaker, J. (1992). (ed). Religion and Mental Health. New York: Oxford University Press.

Singh, B.K., Williams, J.S., \&t Ryther, B. (1986). Public approval of suicide: $A$ situational analysis. Suicide \&t Life Threatening Behavior, 16, 409-418.

Stack, S. (1982) Suicide: A decade review of the sociological literature. Deviant Behavior, 4, 41-66.

Stack, S. (1983). The effect of religious commitment on suicide: A cross-national analysis. Journal of Health and Social Behavior, 24, 362-374.

Stack, S. (1992). Religiosity, depression, and suicide. Pp. 87-97 in Schumaker, J.F. (ed.). Religion \&t Mental Health. New York: Oxford University Press.

Stack, S. (1996a). Does being a parent affect suicide ideology? Omega, 34, 71-80.

Stack, S. (1996b). Effect of female labor force participation on female suicide attitudes. Death Studies, 20, 285-291

Stack, S. (1998a). Gender, marriage, and suicide acceptability: A comparative analysis. Sex Roles, $38,501-520$

Stack, S. (1998b). The relationship between culture and suicide: An analysis of African Americans. Transcultural Psychiatry, 35, 253-269.

Stack, S. (2000a) Suicide: A 15-year review of the sociological literature, Part I. Suicide \& Life Threatening Behavior, 30, 145-162.

Stack, S. (2000b) Suicide: A 15-year review of the sociological literature, Part II. Suicide \& Life Threatening Behavior, 30, 163-176.

Stack, S. (2000c). Blues Fans and suicide acceptability. Death Studies, 24, 223-231.

Stack, S. (2002). Opera subculture and suicide for honor. Death Studies, 26, 431-437.

Stack, S. \& Kposowa, A.J. (2008). The association of suicide rates with individual suicide attitudes: A cross national analysis. Social Science Quarterly, 89, 39-59.

Stack, S. \& Kposowa, A.J. (2011a). Religion and suicide acceptability: A cross-national analysis. Journal for the Scientific Study of Religion, 50, 289-306.

Stack, S., \&t Kposowa, A.J. (2011b). The effect of survivalism- self expressionism culture on black male suicide acceptability: A cross-national analysis. Social Science \&t Medicine, 72, 1211-1218. Stack, S., \& Lester, D. (1991). The effect of religion on suicide ideation. Social Psychiatry \&t Psychiatric Epidemiology, 26,168-170.

Stack, S \& Wasserman, I. (1992). The effect of religion on suicide ideology: An analysis of the networks perspective. Journal for the Scientific Study of Religion, 31, 457-466.

Stack, S. \& Wasserman, I. (1995). The effect of marriage, family, and religious ties on African American suicide ideology. Journal of Marriage Ethe Family, 57, 215-222.

Stack, S., Wasserman, I., \&t Kposowa, A.J. (1994). The effects of religion \& feminism on suicide ideology: An analysis of national survey data. Journal for the Scientific Study for Religion, 33, 110-121. 